\title{
Andrew Wallis, Ambiguous Figures: Interpreting «Zaiae's» Frontispiece
}

\section{Sergio Poli}

\section{Q OpenEdition}

1 Journals

\section{Edizione digitale}

URL: https://journals.openedition.org/studifrancesi/37662

DOI: 10.4000/studifrancesi.37662

ISSN: 2421-5856

\section{Editore}

Rosenberg \& Sellier

\section{Edizione cartacea}

Data di pubblicazione: 15 décembre 2004

Paginazione: 606

ISSN: 0039-2944

\section{Notizia bibliografica digitale}

Sergio Poli, «Andrew Wallis, Ambiguous Figures: Interpreting «Zaiae's» Frontispiece», Studi Francesi [Online], 144 (XLVIII | III) | 2004, online dal 30 novembre 2015, consultato il 08 mai 2021. URL: http:// journals.openedition.org/studifrancesi/37662 ; DOI: https://doi.org/10.4000/studifrancesi.37662

Questo documento è stato generato automaticamente il 8 mai 2021.

\section{(c) (i) (9)}

Studi Francesi è distribuita con Licenza Creative Commons Attribuzione - Non commerciale - Non opere derivate 4.0 Internazionale. 


\section{Andrew Wallis, Ambiguous Figures: Interpreting «Zaiae's» Frontispiece}

\section{Sergio Poli}

\section{NOTIZIA}

ANDREW WALLIS, Ambiguous Figures: Interpreting «Zaiae's» Frontispiece, “Papers on French Seventeenth Century Literature", 59, 2003, pp. 507-516.

Si tratta di un'interessante analisi storico-semiologica dell'immagine riportata sul frontespizio di Zaïde di Mme de Lafayette, incluso nella Lettre à M de Segrais: de l'origine des Romans di Huet e disegnato da Romeyn de Hoogue per l'edizione di Amsterdam del 1671. Gli interlocutori dell'A. sono, oltre al lettore, i critici che si sono occupati dell'argomento, e l'illustrazione della composizione ci porta in una zona in cui si intersecano la riflessione critica, il senso del racconto, l'ordine stesso della società che lo produsse e la concezione del linguaggio che vi si esprime. 